\title{
Itsas ingurumen iraunkorraren bidean: ia emisiorik gabeko ikerketa ontzi hibridoak
}

\author{
(Towards a sustainable marine environment: near-zero emission \\ hybrid research vessels)
}

\author{
Manu Soto*1, Iratxe Olabarri $^{2}$, Gorka Gabiña ${ }^{3}$ \\ ${ }^{1}$ Plentziako Itsas Estazioa. UPV/EHU \\ ${ }^{2}$ Ingeteam Power Technology \\ ${ }^{3}$ AZTI. Arrantza Teknologia Iraunkorrak
}

\begin{abstract}
LABURPENA: Itsas ingurunearen ezagutzak garrantzi handia hartu du azken urteotan, izan ere, bere iraunkortasuna bermatzea jakintza honen konpromezu nagusiena bilakatu da. Euskal Autonomi Erkidegoan itsas ingurunearen oinarrizko ikerketa eta ikerketa aplikatua egiten duten zenbait erakunde daude. Ikerketa taldeek itsasoan dituzte euren ikerkuntza iturri nagusiak. Mota desberdinetako lagin biotiko eta abiotikoak lortzeko, arrantza ontzietan edota ikerketa ontzi ozeanografikoetan itsasoratzea ezinbestekoa izaten dute askotan. Ikerketa egiten duten ontziek garrantzi handiko eginkizuna izaten dute beti, eta egin behar den azterketaren neurrikoa izan behar du behintzat, lanen beharrizanak asetzeko. Ideia honi helduz, Euskal Herriko kostaldean jarduteko balio anitzeko ontzi baten transformazioa izango da artikulu honen lerro nagusia; goi mailako ikerkuntza eta irakaskuntza jasoko dituena. Horretarako, Ingeteam Power Technology enpresak lidertzen duen partzuergo mistoa eratu zen, erakunde pribatu zein publikoekin batera. Helburua, efizientzia energetiko altu eta emisio murritzak bermatuko dituen ikerketa eta irakaskuntza ontzi baten transformazioa da. Pasaiako Blas de Lezo Itsas Arrantza eskolako Ortze ontzia eraldatuko da, hain zuzen, propultsio sistema diesel mekaniko konbentzionaletik propultsio sistema diesel -elektrikora (hibridoa) pasatuz. Proiektua zero-emisio, ekonomia urdin eta garapen iraunkorra jasotzen duen esparruan gauzatzen da. Garapen teknologiko berritzaile honen aurrean, hainbat erabilpen aurreikusten dira: kostaldetik gertu eta ingurune babestuetan zero emisio eta baldintza akustiko baxuetan ikerketa lanak, arrantza alorreko lanbide hezkuntza, propultsio sistema berritzaileaz baliatuz goi mailako graduondoko zein doktorego ikasketak, edota nazioarteko ikerketa taldeen saretzea, besteak beste.

HITZ GAKOAK: ikerketa eta arrantza ontzia, zero emisioak, iraunkortasuna, ekonomia urdina, propultsio sistema dieselelektrikoa (hibridoa), goi mailako irakaskuntza.
\end{abstract}

ABSTRACT: In recent times, marine environment knowledge is taking further concern, focusing all the efforts in guaranteeing its sustainability. The Basque Country has prestigious entities which are involved in elemental and sophisticated applied marine environment research works. The sea is the main source of datum and knowledge for these research teams. For example, all kind of biotic and abiotic sampling are usually extracted by using fishing vessels and oceanographic research vessels, becoming their frequent working platforms. Therefore, research vessels are nearly essential for those works, needed to be at least well dimensioned and prepared for their purposes. In that sense, this article addresses principally the retrofit of a coastal vessel engine propulsion system for high value coastal and near-shore marine research, training and education in the Basque Country. Thus, Ingeteam Power Technology company leads a private and public entities consortium which aims the retrofit, which will improve the vessel's energy efficiency, the manoeuvrability, security and emissions and noise reduction. The vessel, named ORTZE, belongs to the Basque Government, being one of the facilities of the Blas de Lezo, Marine and Fishing School of Pasaia. The retrofit consists of the replacement of the recent diesel mechanic propulsion system for an electric-hybrid propulsion system. The project is placed in a zero-emission, blue economy and sustainability development context. Some purposes are expected in a medium - short term, such as, coastal non-noise and zero-emission research studies, marine and fishing technologies lectures and developments, basic research and master studies and PhD careers on electric propulsion systems, international networking, etc.

KEYWORDS: research and fishing vessels, zero-emissions, sustainability, blue economy, electric-hybrid propulsion system, high level education.

* Harremanetan jartzeko / Corresponding author: Manu Soto, ZBIT ikerketa taldea, Zoologia \& Animalia Zelulen Biologia Saila, Zientzia eta Teknologia Fakultatea, UPV/EHU, Sarriena s/n, E-48940 Leioa; Plentziako Itsas Estazioa. UPV/EHU. Areatza, 48620 Plentzia, Bizkaia. Euskal Herria. - manu.soto@ehu.eus - https://orcid.org/0000-0002-4541-8182.

Nola aipatu / How to cite: Soto, Manu; Olabarri, Iratxe; Gabiña, Gorka (2020). «ltsas-ingurumen iraunkorraren bidean: ia emisiorik gabeko ikerketa ontzi hibridoak»; Ekaia, ale berezia 2020, 57-78. (https://doi.org/10.1387/ekaia.21209).

Jasoa: 31 urria, 2019; Onartua: 12 abendua, 2019

ISSN 0214-9001 - eISSN 2444-3255 / (c) 2020 UPV/EHU

Obra hau Creative Commons Atribución 4.0 Internacional-en

lizentziapean dago 


\section{SARRERA}

Ozeanoek lurrazalaren \% 70 estaltzen dute, baina bakarrik haien $\% 5$ aztertu da xeheki. Itsas esplorazio sakonak XVIII. mendean hasi ziren. Horretarako, oso ospetsuak izan ziren itsasontziak erabili ziren, Endeavour, Beagle, Endurance, Albatross, Challenger, besteak beste [1-7]. xx. mendearen erditik aurrera, aurrerapen teknologikoei esker mundu berri horren inguruko jakintza zabaltzen hasi zen. Gaur egun, ozeanoei esker lurreko bizitza posible dela jakinik, lehentasun zientifikoa bihurtu da ozeanoen ikerketa eta bertan gertatzen diren fenomeno eta baliabideen funtzionamenduaren ulermena, bai eta haien iraunkortasuna ere.

Ikerketa-itsasontziak, edo zentzu zabalagoan itsasontzi ozeanografikoak, funtsezko azpiegituratzat jo daitezke, itsasoak eta haien baliabideak aztertu ahal izateko eta haien kontserbazioa bermatzeko. Plataforma teknologiko konplexuak eta berritzaileak dira, eta ekipamendu eta teknologia sofistikatuz hornituta daude. Adibidez, ezinbestekoak dira datu biologikoak (espezieen banaketa, horien biomasa eta ugaritasuna, tamainaren banaketa) eskuratzeko, heldutasun-egoerak zehazteko, itsas hondoen jarraipena eta haien osasuna ebaluatzeko, bai eta kutsatzaileen ondorioak aztertzeko ere, besteak beste. Horretaz gainera, itsas ekosistemak beren osotasunean aztertzea, hau da, aldagai abiotikoak ( $\mathrm{pH}-\mathrm{a}$, gazitasuna, sakonera, dentsitatea, tenperatura, etab.) eta haien arteko eta aldagai biologikoekiko loturak ikertzea ezinbestekoa suertatzen da kontserbaziorako eta kudeaketa egoki baterako.

Itsas ikerketak ozeanoen eta haien eratorrien iraunkortasuna du jomuga. Horretarako, teknologia berritzaileak erabiltzen ditu bai instrumentazioari bai azpiegiturei dagokienez. Azken horri helduz, itsas ikerketako eta arrantza-irakaskuntzako ontzi baten transformazioa izango da artikulu honen ardatz nagusia.

Hurrengo ataletan, itsas ikerketako ontzien bilakaera, ontzien eraginkortasun energetikoa eta Ortze itsas ikerketa eta arrantza-eskolako ontziaren propultsio eraldaketa aztertuko dira (propultsio sistema diesel konbentzionaletik propultsio diesel-elektrikorako (hibridorako) transformazioa, hain zuzen).

\section{IKERKETA-ONTZIAK}

\subsection{Ikerketa-itsasontzien hastapenak: lehenengo itsas espedizioak}

XV. eta XVII. mendeen bitartean, kolonialismoari eta merkantilismoari estuki lotuta, Europan, esplorazioaren garaia izan zen. Besteak beste, aipagarriak dira Portugaleko koroak Ozeano Atlantikora, Indiara eta Afrikako 
kostaldeetara egindako bidaiak, bai eta Gaztelak Ameriketara egindako bidaiak eta munduko birak ere (Juan Sebastian Elkano eta Magalhaes [8]). Hau da, itsasontzien diseinua eta erabilera inperioak hedatzeko eta lurralde berriekin harreman komertzialak ezartzeko bidea zen (1. irudia). Esplorazio zientifikoaren garaia ondoren etorri zen, eta Ilustrazioaren aroan koka daiteke. Aldi horretan, zientzia eta arrazoiaren kontzeptu berritzaileak ezarri ziren, eta jakin-min zientifikoa ekarri zuen, bide batez espedizio horien bitartez animalia eta landare exotikoak ekartzeko Europara.
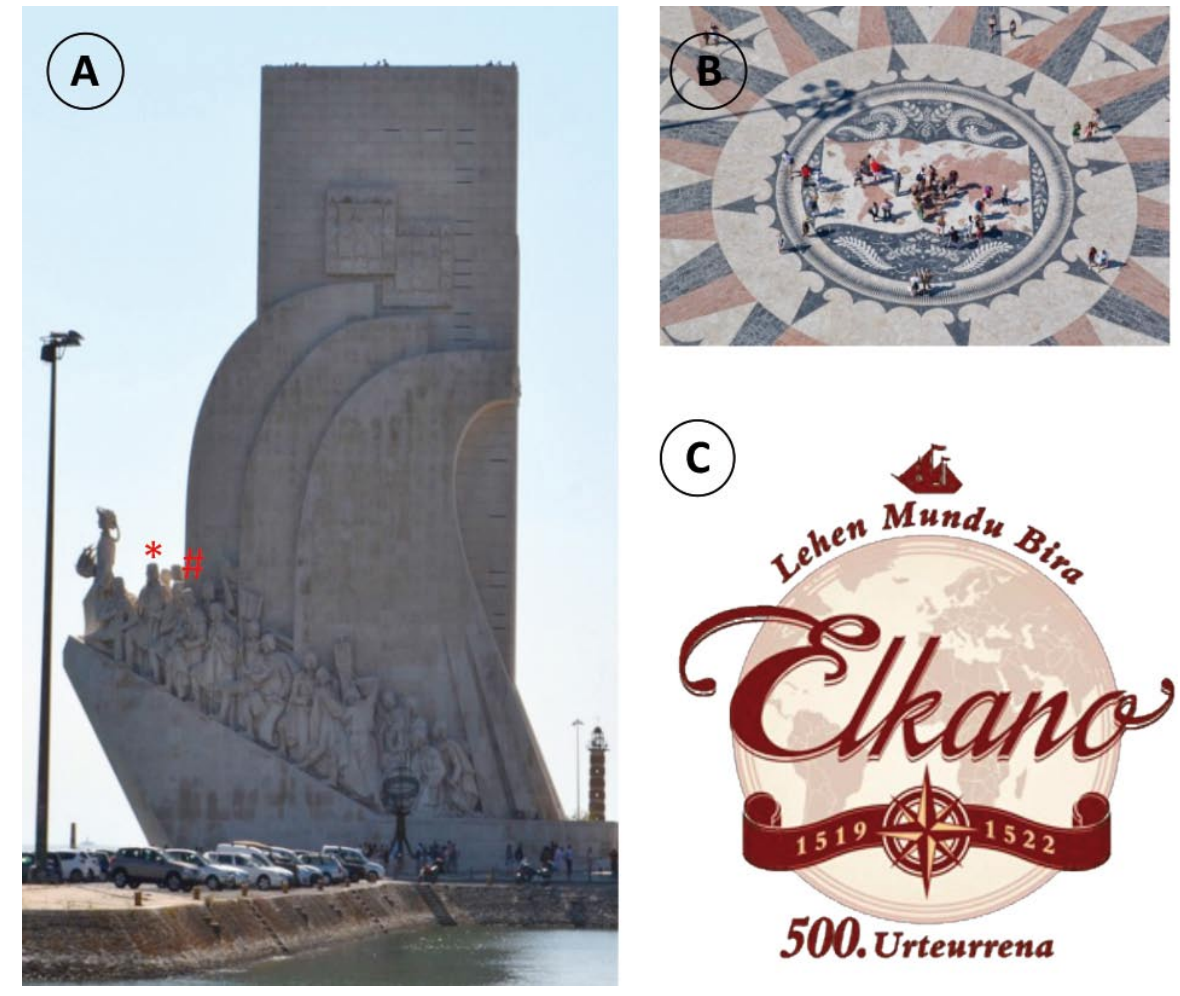

1.irudia. (A) Portugaleko «aurkitzaileak» eta (B) munduan barreneko haien ibilbideak (Belem). (C) Juan Sebastian Elkanoren lehen mundu birako oroitzapena. Ikus Vasco de Gama (*) eta Fernando Magalhaes (\#).

Baina, garai horretan sensu estricton ezin da ikerketa-ontziez hitz egin. Zergatik? Ikerketa-ontzia (ingelesetik research vessel, «RV») itsasoan egindako ikerketarako espresuki diseinatu, aldatu edo hornitutako itsasontzia delako, eta espedizioetan erabiltzen zirenak ez zeudelako helburu horrekin pentsatuta. Arestian aipatu bezala, ikerketa-ontziaren jatorria XVII. mendean izan zen, eta lehenengo esplorazio edo bidaia horietan 
ia itsasontzi guztiak egurrezkoak ziren (2. irudia). Adibidez, James Cooken garaian, 1766. urtean, Royal Societyk Endeavour ontzia uretaratu zuen Ozeano Barean zehar bidaiatzeko eta Artizarraren ibilbidea eguzkian zehar aztertzeko [2]. Itsasontzi horren eraikuntza eta hornikuntza oso modu egokian diseinatu ziren, bidaia luze eta zail batean gerta zitezkeen arazoei aurre egin ahal izateko. Joseph Banks botanikoak hainbat espedizio burutu zituen Endeavour erabiliz. Horri esker 30.000 espezimen bildu zituen, horietatik 1.400 landare espezie berri. Joseph Banks Ingalaterrako Royal Societyko presidentea izan zen 41 urtez (1778-1819) [2].

\subsection{XIX. eta XX. mendeko aurrerapenak}

Beste itsasontzi ospetsua $\boldsymbol{H M S}$ Challenger $^{1}$ (2. irudia) baporez lagundutako korbeta bat zen [7], eta, gerra-kanpainetan parte hartzeaz gain, lehenengo itsas espedizioa burutu zuen, 68.890 itsas miliako ibilbidea (127.580 km) eginez (1873-1876) [1]. Dena den, USS Albatross (2. irudia) jo daiteke lehenengo ikerketa-itsasontzitzat, ikerketarako espresuki diseinatutako lehenengoa izan baitzen (1882) [6]. Haren lehenengo zereginetako bat izan zen AEBko ekialdeko kostaldeko berdelei eta beste espezie migratzaile batzuei buruzko azterketak egitea, bai eta Golkoko korronteak sedimentuetako faunan zer eragin duen aztertzea ere [9]. 1914ko TransAntartikako Espedizio Inperialean, sir Henry Ernest Shackletonek hiru mastako Endurance ('erresistentzia' ingelesez, 2. irudia) bergantina gidatu zuen $[5,10]$. Espedizio hori 1912an Sandefjorden (Norvegia) hasi zen, eta itsasontzia hiru urte geroago Weddell itsasoan (Antartika) izotzak xehatu eta hondoratu egin zen. Tripulazioaren barruan biologoak, fisikariak, geologoak, metereologian adituak, ingeniariak eta argazkilariak zeuden [10]. Garai berean, (1910) Antartikako Espedizio Britaniarrean Terra Nova itsasontzia erabili zen, Robert F. Scott-en gidaritzapean, eta Hego Polora 1912ko urtarrilaren 17an heldu zen. Han ,Roald Amundsenen espedizioa haiek baino 34 egun lehenago heldu zela ikusi zuten [11].

Britainiar armadako HMS Calypso (2. irudia) itsasontzia zena Thomas Guiness dirudunak Jacques-Yves Cousteau ikertzaile ozeanografikoari 1950ean alokatu zion (urteko libera baten truke). Hortik aurrera ikerketa-itsasontzi ospetsuenetako bat bihurtu zen $[12,13]$. Cousteauk urpeko ikerketarako laborategiz hornitu zuen, eta urpekaritza, filmaketa eta oinarrizko ikerketak egin zituen 50 urtez. 1996an istripu baten ondorioz hondoratu zen, eta 1997an (Cousteau zendu zen urtean) hondotik atera zuten, eta oraindik ere jardunean dabil.

${ }^{1} 1983$ eta 1986 bitartean jardunean aritu zen Estatu Batuetako espaziontzi batek izen bera eduki zuen (Space Shuttle Challenger). 

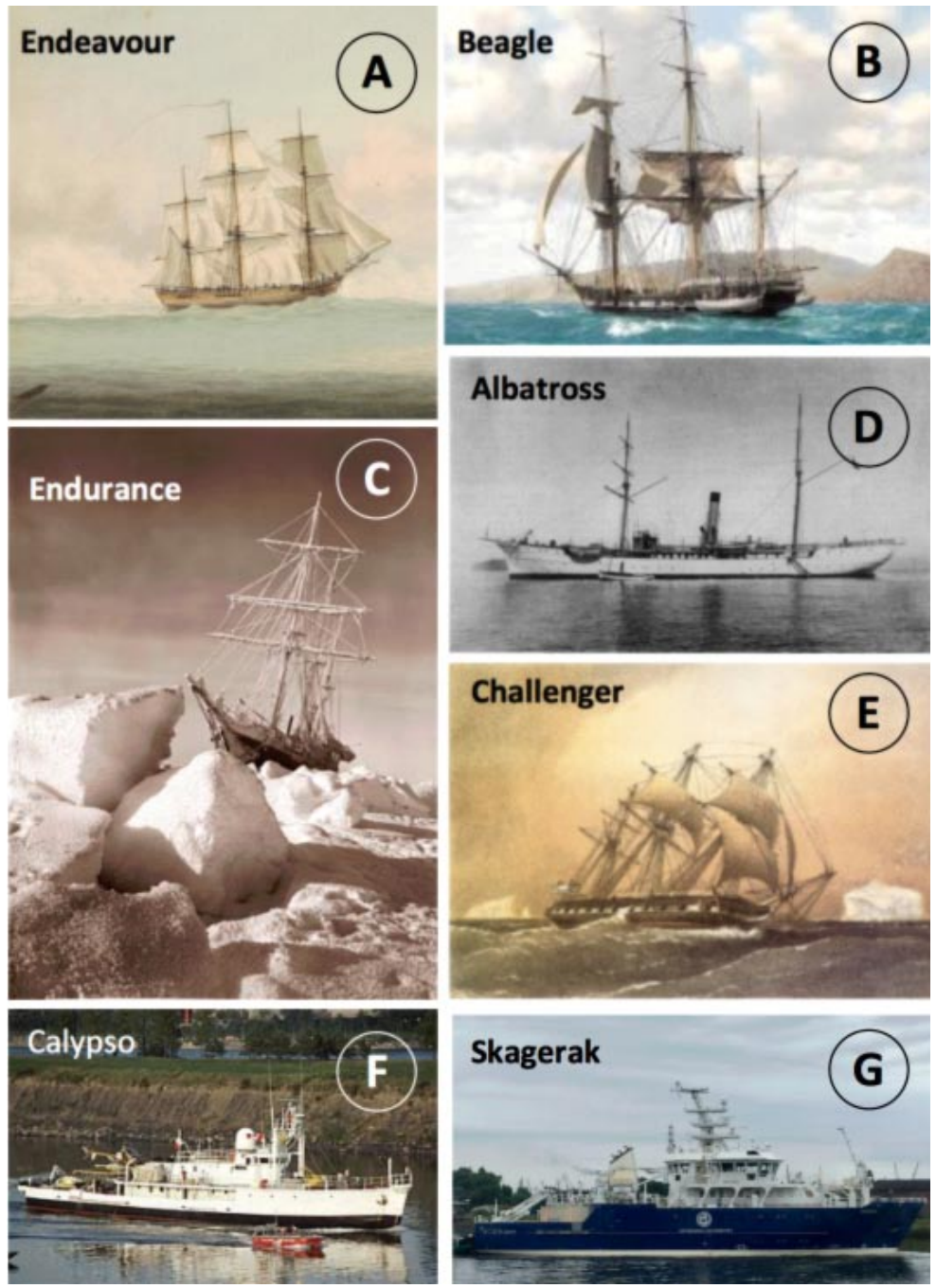

2. irudia. XVII. mendetik XX. mendera, espedizioen edo ikerketarako itsasontzien eboluzioa. Egurrezko itsasontziak (A-F) eta altzairuzkoak (G): A) Endeavour [3], (B) Beagle [4], (C) Endurance [5], (D) Albatross [6], (E) Challenger [7]. (F) Calypso [13], (G) Skagerak [14].

Gaur egungo ikerketa-ontzi aurreratuenak ikerkuntza doi eta zehatzak egiteko diseinatzen dira espresuki, baina beti funtzio aniztasuna bilatuz [14]. Gehienak erakunde publikoek bultzatutako proiektuen bitartez sortuak dira, ikerkuntza zentroak eta unibertsitateko ikertzaileak erabiltzeko. Adibide batzuk 1. taulan laburbildu dira. 
1. taula. Ikerketa-ontzien (RV) adibide batzuk, zer erakundek operatzen dituzten eta zein helburu betetzen dituzten adierazita.

\begin{tabular}{|c|c|c|c|}
\hline Izena & Urtea & Erakundeak edota erabileak & Helburua \\
\hline RV Lura & 1981 & \multirow{4}{*}{$\begin{array}{l}\text { IEO } \\
\text { (Espainiako Ozeanografia }_{\text {Institutua })^{2}}\end{array}$} & $\begin{array}{l}\text { Kostaldeko ekologiako kan- } \\
\text { painak (Galizian) }\end{array}$ \\
\hline $\begin{array}{l}\text { RV Francisco de } \\
\text { Paula Navarro }\end{array}$ & 1987 & & \multirow{3}{*}{$\begin{array}{l}\text { Laginketak: ura eta sedimen- } \\
\text { tuak; itsasoko uraren aldagai } \\
\text { fisiko eta kimikoen azter- } \\
\text { keta, itsas flora eta faunaren } \\
\text { inguruko ikerketa lanak. }\end{array}$} \\
\hline $\begin{array}{l}\text { RV Ramón } \\
\text { Margalef }\end{array}$ & 2011 & & \\
\hline $\begin{array}{l}R V \text { Ángeles } \\
\text { Alvariño }\end{array}$ & 2012 & & \\
\hline Thalassa & 1996 & IEO eta IFREMER & $\begin{array}{l}\text { Arrantza ikerketa Ipar Itsa- } \\
\text { soan }\end{array}$ \\
\hline Hesperides & 1991 & CSIC & Ikerketa polarra \\
\hline Vizconde de Eza & 2000 & \multirow{2}{*}{$\begin{array}{l}\text { MAPAMA Ministerio de } \\
\text { Agricultura, Alimentación } \\
\text { y Medio Ambiente }\end{array}$} & Arrantza ikerketa \\
\hline $\begin{array}{l}\text { RV Emma } \\
\text { Bardan }^{5}\end{array}$ & 2006 & & $\begin{array}{l}\text { Itsas hondoen kartografiak, } \\
\text { ozeanografia eta arrantzako } \\
\text { datuen jasotze lanak. }\end{array}$ \\
\hline$R V$ Socib & 2012 & $\begin{array}{l}\text { SOCIB. Balearic Islands } \\
\text { Coastal Observing and Foi- } \\
\text { recasting System (MICyU, } \\
\text { Spain) }\end{array}$ & $\begin{array}{l}\text { Prozesu ozeaniko globalen } \\
\text { ikerketa }\end{array}$ \\
\hline$R V$ Investigator & 2014 & $\begin{array}{l}\text { Commonwealth Scientific } \\
\text { and Industrial Research Or- } \\
\text { ganisation (CSIRO), Austra- } \\
\text { lia's Marine National Facility }\end{array}$ & Ikerketa polarra \\
\hline $\begin{array}{c}\text { RV Neil } \\
\text { Armstrong }\end{array}$ & 2015 & $\begin{array}{l}\text { Woods Hole Oceanographic } \\
\text { Institution }\end{array}$ & $\begin{array}{l}\text { Ikerketa ozeanografiko au- } \\
\text { rreratua ozeano tropikal eta } \\
\text { epeletan }\end{array}$ \\
\hline$R V$ Havfisken & 2015 & DTU Aqua (Denmark) $)^{4}$ & $\begin{array}{l}\text { Arrantza, ozeanografia eta } \\
\text { ingurumen monitorizazioa, } \\
\text { akustika, urpeko filmazioa } \\
\text { ROVekin, laginketak, etab. }\end{array}$ \\
\hline
\end{tabular}

${ }^{2}$ Espainiako Ozeanografia Institutua (IEO): http://www.ieo.es/es/web/ieo/flota

${ }^{3}$ MAPAMA; Emma Bardan itsasontzi ozeanografikoa: https://preservicio.mapama.gob. es/es/pesca/temas/proteccion-recursos-pesqueros/buques-secretaria-general/investigacionpesquera-oceanografica/emma-bardan/

${ }^{4}$ DTU Aqua: https://www.aqua.dtu.dk/english/about/facilities/smaller-research-vessels 
Itsas ingurumen iraunkorraren bidean: ia emisiorik gabeko ikerketa ontzi hibridoak

\begin{tabular}{|c|c|c|c|}
\hline Izena & Urtea & Erakundeak edota erabileak & Helburua \\
\hline $\begin{array}{l}R V \text { Dr Fridtjof } \\
\quad \text { Nansen }\end{array}$ & 2016 & $\begin{array}{l}\text { Norwegian Agency for De- } \\
\text { velopment Cooperation } \\
\text { (NORAD), Inst Marine Re- } \\
\text { search (IMR), Bergen Uni- } \\
\text { versity }\end{array}$ & $\begin{array}{l}\text { Garapen bidean dauden he- } \\
\text { rrialdeei beren arrantza ku- } \\
\text { deatzen laguntzeko }\end{array}$ \\
\hline $\begin{array}{l}\text { RV Kronprins } \\
\text { Haakon }\end{array}$ & 2018 & $\begin{array}{l}\text { University of Troms } \varnothing \\
(50 \%) \text {, Norwegian Po- } \\
\text { lar Institute }(30 \%) \text { Norwe- } \\
\text { gian Institute of Marine Re- } \\
\text { search }(20 \%)\end{array}$ & $\begin{array}{l}\text { Ontzi izotz-hausle, ozeano- } \\
\text { grafia Zirkulu Artikoan }\end{array}$ \\
\hline $\begin{array}{l}R V \text { Electra } A f \\
\text { Asko }\end{array}$ & 2016 & $\begin{array}{l}\text { Stockholm University Bal- } \\
\text { tic Sea centre }\end{array}$ & $\begin{array}{l}\text { Ontzi izotz-hausle, ikerketa } \\
\text { Itsaso Baltikoan }\end{array}$ \\
\hline B.A.P. Carrasco & 2017 & Peruvian Navy & $\begin{array}{l}\text { Ikerketa ozeanografikoa, Pe- } \\
\text { ruko uretan eta Antartikan } \\
\text { zehar }\end{array}$ \\
\hline $\begin{array}{c}R V \\
\text { Skagerak }^{5}[14]\end{array}$ & 2017 & University of Gothenburg & $\begin{array}{l}\text { Ikerketa: biologia, ozeano- } \\
\text { grafia, geologia, kimika, } \\
\text { arrantza }\end{array}$ \\
\hline$R V$ Tidewater & 2019 & $\begin{array}{l}\text { Virginia Institute of Marine } \\
\text { Science - VIMS }- \text { (USA) }\end{array}$ & $\begin{array}{l}\text { Funtzio anitzeko ontzia; es- } \\
\text { tuarioetan eta kostaldeetan } \\
\text { jardutekoa. }\end{array}$ \\
\hline
\end{tabular}

Hala ere, itsasontzi aurreratuenek ere iraunkortasuna dute helburu, beren operazio lanak ahalik eta aztarna ekologiko murritzena izan dezaten. Hurrengo atalean adieraziko den bezala, energiaren erabilera murriztea da gaur egungo ontzien erronka nagusienetarikoa. Horretan ere ikerketa ontziak sartzen dira.

\section{ENERGIA ETA IRAUNKORTASUNA ITSASONTZIETAN}

Itsasontzi batek behar duen energia, kasu gehienetan, motor termikoen bidez hornitzen da. Horiek, era berean, petroliotik eratorritako erregai fosilekin elikatzen dira. Erregai fosilak, munduan erabiltzen diren energia iturri ugarienak dira; energia iturri ez berriztagarriak, alegia.

\footnotetext{
5 https://www.eurofleets.eu/vessel/rv-skagerak/

${ }^{6}$ Virginia Institute of Marine Science (VIMS): http://www.vims.edu/intranet/ operations/vessel_operations/index.php
} 
Petrolioaren prezioaren bilakaera ezegonkorra da. Joera horretan, hainbat faktorek dute eragina, hala nola produkzio kostuak, herrialde produktoreetan gertatzen diren egoera geopolitiko edo estrukturalak, zein momentuko merkatu baldintzak, besteak beste $[15,16]$. Hurrengo irudian, petrolio upelaren azken hamabost urteetako prezioaren bilakaera ezegonkorra adierazten da (3. irudia) [17]. Itsas industriaren kezka nagusietako bat erregai gastua da. Izan ere, itsasontzi batek duen erregai kontsumoa bere operazio gastuen parte handi bat izaten da (\% 60-70 ere bai) [18]. Arrantzan diharduten ontzien kasuan, adibidez, erregai kontsumoa haien operazio gastuen $\% 50$ gorakoa ere izan daiteke [19].

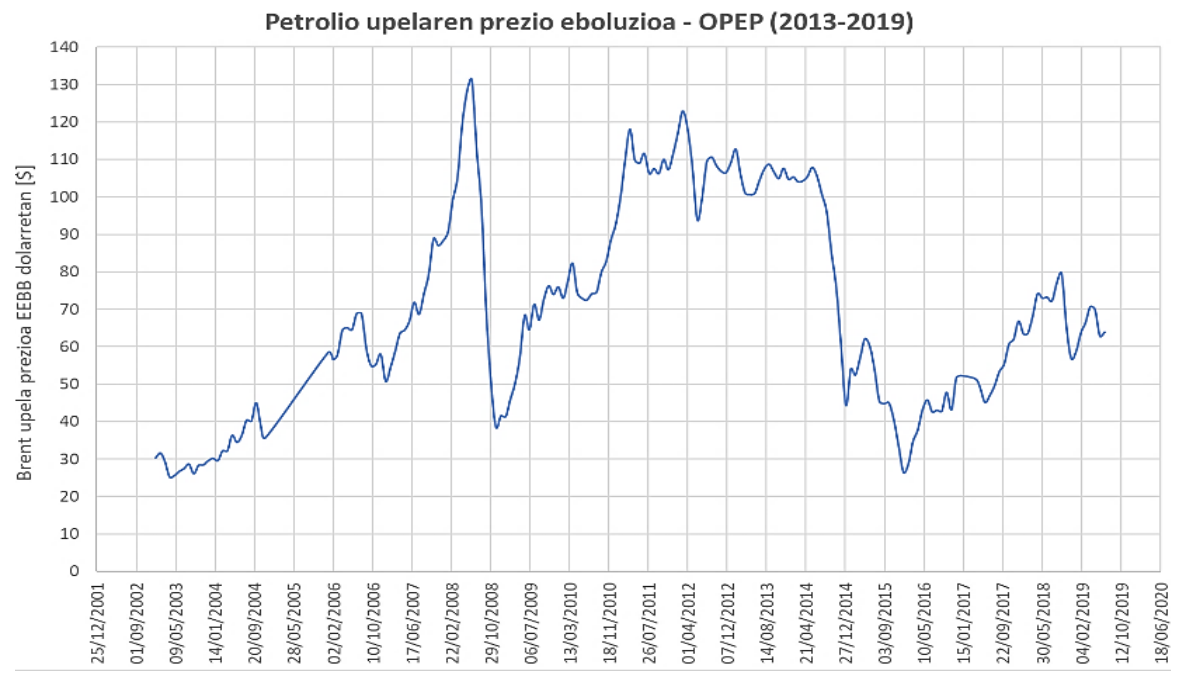

3. irudia. Petrolio upelaren prezioaren bilakaera (grafikoa egiteko datu iturria [17])

Hasieran aipatu bezala, itsasontzien energia hornitzea makina eta motor termikoen bidez egiten da. Makina horien artean ohikoenak diesel motorrak dira. Urtean, itsasoan erabiltzen diren diesel motorren kontsumoa mundu mailan oso altua da, ia 60 milioi upel [20]. Horrek emisio kopuru hauek dakartza urtean: 961 milioi tona $\mathrm{CO}_{2}, 21$ milioi tona $\mathrm{NO}_{\mathrm{X}}, 11,3$ milioi tona $\mathrm{SO}_{\mathrm{X}}$ eta 1,4 milioi tona partikula isurketa atmosferara [21].

IMO (International Maritime Organization) erakundeak, 2015az geroztik, ingurumenaren gaineko politika murritzaile eta zorrotzagoak ezarri ditu. Besteak beste, erregaiaren sufre kantitateak ezin izango du \% 0,1eko muga gainditu ECA (Emission Control Area) guneetan (Ipar Ameri- 
kako kostaldea, Ipar Itsasoa eta Itsaso Baltikoa), eta gainontzeko zonetan $\%$ 0,5eko muga ezarriko da 2020. urterako [22]. $\mathrm{NO}_{\mathrm{X}}$ emisioei dagokienez, TIER erregulazioa (IMO) sartzen da, motorrei aplikatutako erregulazioa, alegia. Jada 2016. urtetik, TIER III abian jarri da, $\mathrm{NO}_{\mathrm{x}}$ gabeko ECA zonetan, non $\mathrm{NO}_{\mathrm{X}}$ emisioen murrizpena, TIER II-rekin konparatuz, \% 75ekoa den [23]. $\mathrm{CO}_{2}$ emisioei dagokienez, kontrol berriak jarri ziren martxan 2016an, batez ere itsasontzi handietarako ( $>400 \mathrm{GT}$ ), non eraginkortasun energetikoan oinarritutako indize eta indikatzaile batzuk ezarri ziren (EEOI - Energy Efficiency Operational Indicator, EEDI - Energy Efficiency Design Index), eta SEEMP (Energy Efficiency Management Plan) itsasontziaren eraginkortasun energetikoa kudeatzeko plana ere jarri zen martxan.

Beraz, azken urteotan, itsasontzien eraginkortasun energetikoak erabateko garrantzia hartu du. Izan ere, bai energiaren kostua bai ingurumenaren aldeko konpromisoak direla eta, operazio eta prozesuen eraginkortasun energetikoa aukera bat izatetik beharrizan bat izatera igaro da [24]. Hori dela eta, azken urteotan, itsas sektoreko agente desberdinak neurriak diseinatzen eta garatzen hasi dira berriki aipatutako mugen barruan [25]. Ontzi barruko energia-kontsumo aurrezpen estrategiak ondo definitu behar dira. Horretarako, auditoretza energetiko sakon bat egin behar da ontzi barruan, energia kontsumoko patroiak ondo definituz eta horrekin neurriak eta estrategiak diseinatuz.

Estrategia horiek ontziaren dimentsio osoan diseinatzen dira, hau da, makineriaren, operazioen, erregaiaren zein ontzia beraren ezaugarri estrukturalen ikuspegitik. Bestetik, ontziaren diseinuaren hastapenetan proiektatzen diren neurriak errazago ezartzen dira. Aurrerantzean neurri interesgarriak ezar daitezke, baina betiere zailtasun handiagoarekin, bai teknikoki, bai ekonomikoki.

Ontzi barruko energia-kontsumoa kudeatzeko sistemak, hala nola propultsio motorren aldiuneko erregai kontsumoaren adierazgailuak, eragin handia izan dezakete operazioaren kontsumo ereduan. Arrantza ontzietan, adibidez, \% 10-25eko aurrezpenak ekar ditzakete, arrantza motaren arabera [19].

Propultsio sistemaren operazio moduarekin jarraituz, nabigazio motelak edo geldoak (slow steaming deiturikoa) aztertu izan dira, batez ere ibilbide luzeetako itsas garraiorako. Neurri honek erregai aurrezpena ekar dezake, baina era berean zerbitzu denbora luzatu, eta produktu edo zerbitzuaren kalitatea mugatzen du. Hori dela eta, tokian tokiko azterketa behartzen duen soluzioa da, hain zuzen [26]. Aurreko kasuan, neurria ezartzea errazago izan daiteke, beste soluzio berritzaile batzuekin alderatuta, hala nola haize-energiako propultsio sistemak. Oraindik teknologiaren ezarketaren ikuspuntutik heldutasuna behar du, batik bat azterketa eta 
proba kopuru aldetik, adibidez slow steaming operazio moduarekin alderatuz gero [27].

Aurreikusitako operazio-baldintzak kontuan hartuz motorren mantenu (CBM - Condition Based Engine Maintenance) egoki batek erregai kontsumoaren murrizketa ere ekar dezake. Ikerketa lanetan berretsi den bezala, hainbat faktorek eragina izan dezakete motorren funtzionamendu desegoki batean, hala nola buxadurak turbokonpresorean zein aire hozte sisteman, injekzio ponpatze txarra, etab. [28].

Beste teknika berritzaile batzuk aztertuta, egun, aurrerapausoak ematen ari dira ORC motako (Organic Rankine Cycle) teknologiarekin; motorren bero galerak berreskuratzean datza, bero-galera horietatik energia sortuz [29].

Erregaiaren gaineko ikerketak egin dira, polarizadore magnetikoak aztertuz, aurrezpen nabarmenak aurkituz [30] edota ez hain nabariak [31]. Erregai alternatiboen kasuan, ikerketa lan anitz aurki daitezke bibliografian bai biodieselen kasuan [32,33], bai, neurri murritzagoan, mineral jatorriko erregai alternatiboetan non eragin positiboak ondoriozta daitezkeen, kontsumo eta emisio aldetik [34].

Beste neurri batzuen artean, propultsio sistema berritzaileak aurkitzen dira, belaunaldi berriko sistema elektrikoetan oinarritzen direnak hain zuzen. Hainbat ikerketa lan egiten ari dira ontzien elektrifikazioaren esparruan; propultsio elektrikoaren garapenak etorkizun hurbileko Karbono Baxuko Ekonomiako inguru baten etorrera bultzatuko du [35, 36]. Artikulu honen gai nagusiak azken neurri horren ildoari jarraitzen dio, hurrengo ataletan zehatzago adieraziko den bezala.

\section{ITSASONTZIAREN AUKERAKETA}

Aurretik aipatu diren gaiei helduz, ardatz trinko bat azpimarratu daiteke: ikerketa ontzi efizienteak. Kasu honetan, ikerketarako eta ikaskuntzarako bideratuko den ontzi baten propultsio sistemaren eraldaketa aukeratu da. Ontzi berri baten fabrikazioa inbertsio handia da. Beraz, egungo ontzi baten birmoldaketa planteatu da teknologia berritzaile bat instalatzeko. Aukeratutako itsasontzia Pasaiako Blas de Lezo Itsas Arrantza BHIk (Bigarren Hezkuntza Institutua) duen ORTZE ontzia izan da, zein Eusko Jaurlaritzaren ontzi flotako parte den. 


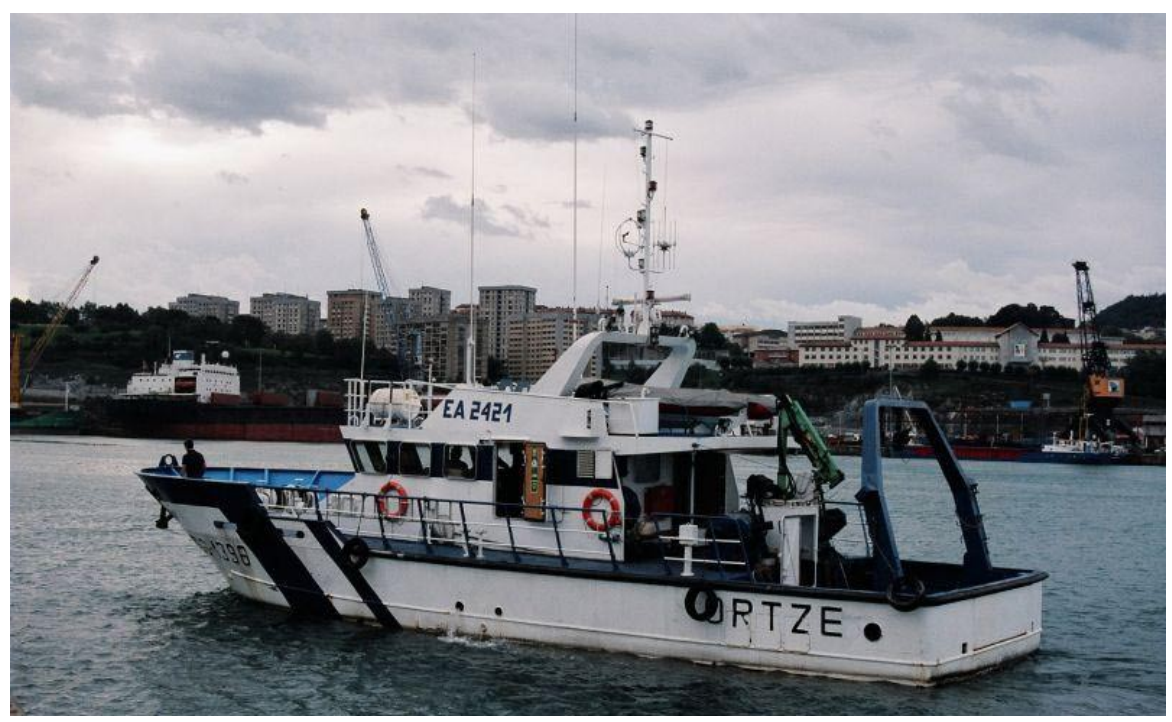

4. irudia. ORTZE itsasontzia.

ORTZE itsasontzia, arrantzaren ikuspuntutik, arrasteko operazioan eta arrantza mota estatikoekin aritzeko prestatuta dagoen arrantzarako eskola-ontzia da. Burdinazko xaflaz fabrikatu zen 1996. urtean Astilleros Ascorreta ontziolan. Kubierta edo ontzigaina zabala du eta brankan (aurrealdean) ainguratzeko sistemak (makina birakor edo gindax bi) ditu. $\mathrm{Ku}-$ biertaren erdian zubia dago, estruktura handi batez osatua. Zubitik popara (atzealdea), goiko kubiertaren erdian garabia eta albo bakoitzean (ezkerraldean eta eskuinaldean) arrantza makina birakorrak daude, arrasteko operazioetarako (kablea erriatzeko edo jasotzeko) erabiltzen direnak. Popan, beheko ontzigaina edo arrantza kubierta dago. Bertan, popan portiko etzangarri bat dago, gailu ozeanografikoak jaurti eta jasotzeko, hala nola buiak, CTDak (eroangarritasuna, sakonera eta tenperatura neurtzeko zunda), itsas hondoko filmaziorako ROV (Remote Operated Vehicle), eta abar. ORTZE ontziaren neurri orokorrak 2. taulan adierazten dira.

2. taula. ORTZE ontziaren neurri orokorrak.

\begin{tabular}{lc}
\hline \multicolumn{1}{c}{ Ezaugarriak } & Neurria (m) \\
\hline Esloi totala (luzera) & 19,02 \\
Perpendikularren arteko esloia & 16,00 \\
Manga (zabalera) & 6,00 \\
Puntala goiko kubiertara (sakonera) & 3,15 \\
\hline
\end{tabular}


Horrelako ezaugarriak kontuan hartuta, gaur egun ORTZE itsasontziak hainbat arrantza-operazio egiten ditu: hondoko arrastea, tretza, berdeletarako linea bertikala eta hegaluzetarako kaza arrantza mota, besteak beste. Kostaldeko nabigazioa, maniobra lanak eta makinako zaintzak ere irakasten dira ontzi honetan. Hogei bat metro luzerako itsasontzi honen egungo propultsio sistema motor diesel konbentzionala da $(800 \mathrm{cv})$; hori dela eta, isurketak (bai gas kutsakorrei bai akustikari dagokienez) nahiko handiak dira. Azterketa sakon baten ostean, Ortzeren propultsio sistema konbentzionaletik berritzailera igarotzea aukera egokia dela ondorioztatu da, betiere ingurumenaren iraunkortasuna jomugatzat harturik. Ontzi hau helburu zientifikoetarako erabat erabilgarria bihur daiteke eraldaketa sakon bat jasoz gero, ikerketa-itsasontzi gisa erabiltzeko, alegia.

\section{ORTZE ONTZIAREN ERALDAKETA: PROPULTSIO SISTEMA DIESEL-ELEKTRIKOA (HIBRIDOA)}

Eraldaketa honen helburu nagusia ontziak egingo dituen jardueren aztarna ekologikoa ahalik eta gehien murriztea da, teknologia berritzaile baten bidez. Hain zuzen ere, zero emisioko egoera lortu nahi da portuetan (itsasoratze eta lehorreratze ibilbideetan) eta babestutako inguruneetan edo jendartetik gertuko guneetan [37]. Oro har, aurreikusita dago isurketak $\% 25$ baino gehiago murriztuko direla egungo sistemarekin konparatuta. Horrekin batera, erregaien kontsumoa ere murriztuko da neurri berdinean. Eraldaketa honen puntu esanguratsu bat ontziak izango duen nabigazio isila da, zeinak ingurumena babestu, inguruko itsas sistema eta animaliei kalterik egin gabe, eta kalitatezko ikerketa jarduera konplexuak ahalbidetuko dituen.

Propultsio sistemaren eraldaketa propultsio motor elektrikoa ezarri eta planta diesel-elektriko (hibridoa) lortzean datza. Proposatutako irtenbideek egungo joerak gainditzen dituzten eta gertuko etorkizunean eskatuko diren berrikuntza teknologikoak eskaintzen dituzte. Egungo Ortze ontziko helizea diesel motorrak birarazten du, baina, eraldaketaren ostean, helizea biraraziko duen motorra elektrikoa izango da. Motor elektrikoa biratzeko behar den energia iturri desberdinetatik etorriko da (eguzki panelak, diesel sorgailu elektrikoa eta bateriak). Ontziak modu diesel-elektrikoan (diesel sorgailu batek hornituko luke motor elektrikoak behar duen energia) edo modu guztiz elektrikoan (bateriek eta eguzki panelek hornituko lukete motor elektrikoak behar duen energia) egin dezake lan. Modu guztiz elektrikoan, zero emisio lortuko da, 2 orduz gutxienez, portutik irtetean edo portura heltzean, babestutako inguruneetan, eta abiadura txikian egin behar diren operazio zehatz eta isiletan.

Frekuentzia bihurgailuek energia iturri desberdinek sortutako potentzia elektrikoaren konbertsio eta egokitzapena bideratzen dute, itsasontziko karga desberdinek eskatzen dituzten uhin formetara moldatuz. 
Propultsio nagusiko motorrek eta maniobra helizeek uhin forma aldakorra behar dute, bai tamainan bai maiztasunean, haien abiadura kontrolatu ahal izateko, bai eta estatoretik zirkulatzen duten korronteen kontrol zehatza bermatzeko ere. Beste karga batzuek, hala nola hotel motatakoak, elektroponpa laguntzaileek, tentsio alterno konstantea behar dute (Vac), bai tamainan bai maiztasunean.

Baterien kasuan, zeinek energia iturri zein karga gisa funtziona dezaketen, frekuentzia bihurgailuak baterien karga eta deskarga kontrolatzeko beharrezkoak dira. Tentsioak egokitu eta korronteak kontrolatzen dituzte, bateriek kalterik jaso ez dezaten eta haien bizialdia ahalik eta luzeena izan dadin. Gainera, frekuentzia bihurgailuek potentzia fluxua, bai eta sorrera eta eskaeraren arteko banaketa eta balantzea ere kontrolatzen dituzte, energia kudeaketa medio, itsasontziaren operazio modu desberdinetan sistemaren efizientzia energetiko orokorra maximizatuz.

5. irudian ikusten dugun propultsio nagusiko motor elektrikoa korronte alternokoa da, trifasikoa, iman iraunkorretako sinkronoa, eta bere estatorean debanatu bikoitzekoa da. Bere abiadura eta potentzia nominalak $1.800 \mathrm{rpm}$ eta $500 \mathrm{KW}$ dira, hurrenez hurren.

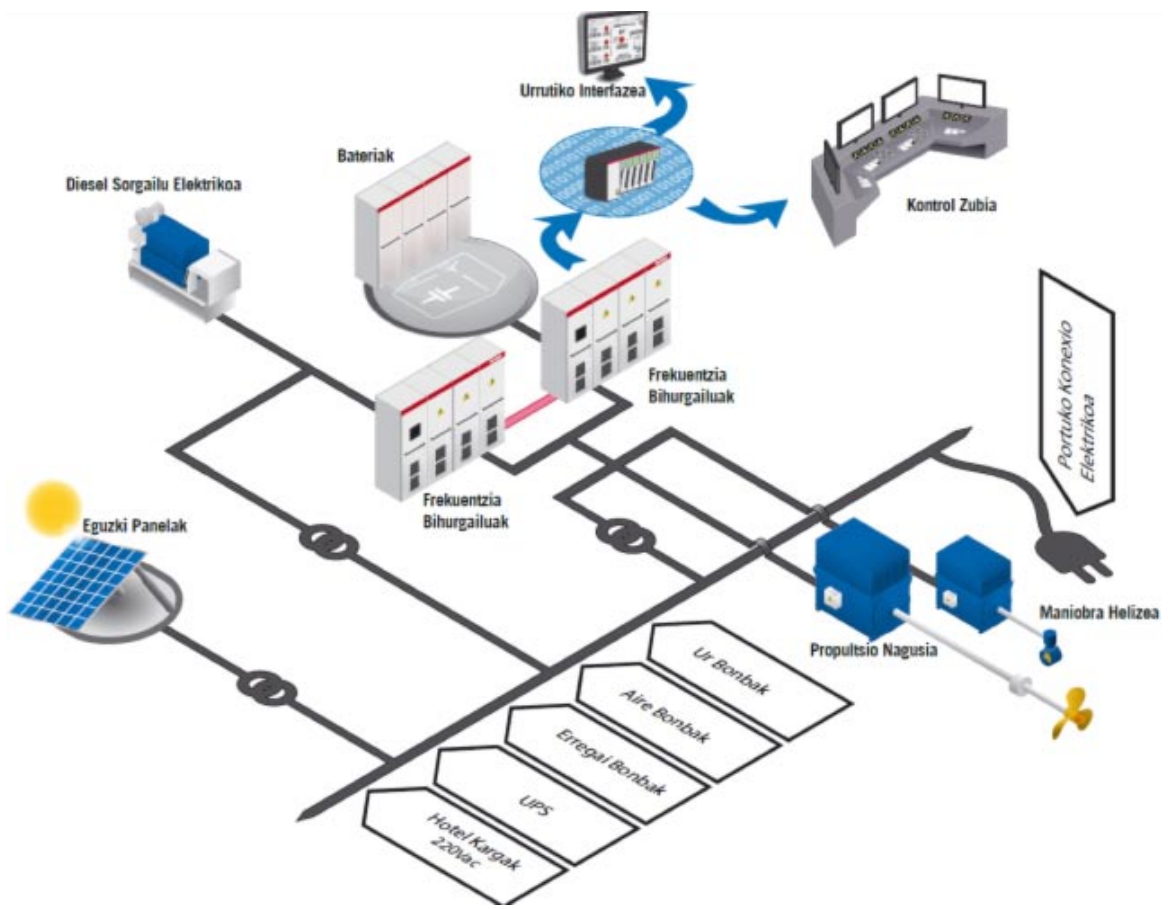

5. irudia. ORTZE ontziko energiaren banaketaren eskema orokorra. 
Maniobra helizeko motorra, $1.500 \mathrm{rpm}$ eta $20 \mathrm{~kW}$-koa da. Karga elektriko laguntzaileek, hala ur gazi zein gezako zirkuituetan, nola aire, olio edo erregai zirkuituetan, hotel motako kargekin batera, $40 \mathrm{kVA}$ inguru gehitzen dituzte, eta tentsio eta maiztasun konstanteetan dihardute $(3 \times 220 \mathrm{Vac}, 50 \mathrm{~Hz})$.

Bateriek $200 \mathrm{kWh}$ arteko energia pila dezakete, eta $400 \mathrm{~kW}$ arteko potentzia elektrikoa jaso edo emateko gai dira. 40 minutuan erabat kargatuta egon daitezke, eta haien tentsio nominala 850 Vdc-koa da. Diesel sorgailu elektrikoak $325 \mathrm{kVA}$ arteko potentzia sor dezake, 400 Vac-ko tentsio trifasikoan eta $60 \mathrm{~Hz}$-eko maiztasunean.

Eguzki paneletan oinarritutako energia berriztagarriko iturriei dagokienez, potentzia elektrikoa sortzeko gaitasuna $5 \mathrm{~kW}$-ekoa da. Energia iturri horrek bere bihurgailua darama barruan, sortutako potentzia elektrikoak $220 \mathrm{~V}$-eko korronte alterno trifasikoa, $50 \mathrm{~Hz}$-ean, izan dezan.

Ortze ontzian ezarriko diren teknologia eta sistemak potentzia sistema bateratu baten inguruan arituko dira, eta haien ezaugarri nagusiak, laburrean, ondokoak dira:

1. Motor elektriko bidezko propultsio hibridoa. Motor hau goi efizientzia energetikokoa eta operazio isilekoa da.

2. Korronte zuzen bitarteko potentzia banaketa.

3. Ontzi barruko segurtasun eta erredundantzia maila altua.

4. Neurrizko hasierako kostua eta operazio kostu murriztuak.

5. Urrutitik mantendu eta gainbegiratu daiteke, jarraitze eta mantentze prebentibo eta prediktiboko sistemak barneratuz.

6. Sortutako, gordetako eta kontsumitutako potentzia eta energia optimizatzen da, «burmuin elektroniko» bitartez kudeatuz.

7. Itsasontziak behar duen energia elektrikoa iturri batetik baino gehiagotatik sortzen da:

a) Diesel sorgailu elektriko bitartez, energia elektrikoa maiztasun aldakorrean sortuz.

b) Eguzki panelak, energia fotovoltaikoa dela medio.

c) Baterien bidez. Bateriak itsasontzia portuan geldi dagoenean energia berriztagarriak erabiliz kargatu daitezke, portutik irtetean modu elektrikoa bermatzeko. Ontzia itsasoan dagoenean ere bateriak sorgailu elektrikoaren nahiz eguzki panelen bidez kargatu daitezke. Horrela itsasontzia portura bueltatzean bateriak kargatuta egongo dira, eta itsasontzia modu guztiz elektrikoan sartu ahalko da portuan.

Energia efizientzia handiko frekuentzia bihurgailuen erabilera. ORTZE itsasontzi berriztatuak ondoko operazio moduak lortuko ditu: 
- Portuan dagoenean, lurrera konektatutako modua: diesel sorgailu elektrikoa itzalita dago, energia iturria portuko sare elektrikoa izanik. Portuan bateriak kargatzeko aukera dugu, energia berriztagarriak soilik erabiliz.

- Nabigazio modu guztiz elektrikoa. Kasu honetan, sorgailu elektrikoa guztiz itzalita dago. Eta energia iturri gisa bateriak eta eguzki panelak erabiliko ditugu. Eskuragarri dugun potentzia maximoa $350 \mathrm{~kW}$ da. Energia maximo eskuragarria $200 \mathrm{kWh}$ da. Portuetako sarrera eta irteeretan, bai eta babestutako inguruneetan erabiliko da, eta modu horretan isurpen maila zero da. Kasu honetan, haren autonomia 23 mn 6 kn-koa da.

- Nabigazio modu diesel elektrikoa. Sorgailu elektrikoa piztuta dago, bateriak deskonektatuta daude, eta energia iturriak sorgailu elektrikoa eta eguzki panelak dira. Potentzia maximo eskuragarria $320 \mathrm{~kW}$ da.

- Nabigazio modu hibridoa. Sorgailu elektrikoa piztuta dago, bateriak konektatuta daude, eta energia iturriak, beraz, sorgailu elektrikoa, bateriak eta eguzki panelak dira. Potentzia maximo eskuragarria $600 \mathrm{~kW}$ da, baterien karga \% 50 baino handiagoa den egoerentzat. Modu hibridoan sortutako energia bateriak berriro ere kargatzeko erabil daiteke. Modu hori kostaldetik urrunago dauden lekuetan erabiltzen da.

\section{PROIEKTUAREN KIDEAK}

Arestian esan bezala kostaldeko eta kabotajeko itsasontzietan ezarriko diren efizientzia energetiko altuko eta isurpen murritzeko (bai gas kutsagarriei eta bai eta akustikoei dagokienez ere, eta zero isurpen inguru babestuetan) irtenbideak ikertzeko eta garatzeko funtsezko xedearekin sortu da ORTZE-CV (Research \& Development of Technologies towards Zero Emission Coastal Vessels) proiektua.

Aurreikusita dauden I+G (Ikerkuntza eta Garapena) ekintzei esker, itsasontziek inguruko ekosistemetan ahalik eta inpakturik txikiena sortuz gauzatu ahal izango dituzte kostaldeko jarduerak. Makina gelaren eraldaketa honek ere propultsio sistema berritzailea ekarri du, eta itsas eta arrantza irakaskuntzaren ikuspegitik posizio ezin hobean utziko du arrantza eskola, erreferentzia zentro bihurturik. Eraldaketa osteko Ortze ontzia, eskola itsasontzia izateaz gainera, itsasoari eta ingurumenari buruzko ikerketa lanak egiteko ere erabiliko da. Lehen aipatu bezala, erreferentea bilakatuko da tokian tokiko eremuan zein nazioartekoan, bai instalatuko diren teknologiengatik baita beteko diren jarduerengatik ere. Proiektu hori aurrera ateratzeko Euskal Autonomia Erkidegoko zenbait enpresa eta erakundek osatutako partzuergoa sortu da (3. taula), Ingeteam enpresa proiektuaren liderra izanik. 
3. taula. ORTZE proiektuko partzuergoko kideak.

\begin{tabular}{|c|c|}
\hline Kideak & Zeregina \\
\hline INGETEAM & $\begin{array}{l}\text { Proiektu burua. Potentzia eta kontroleko elektronikaren, sistema } \\
\text { bateratzearen, kudeaketa energetiko optimoaren, energia berrizta- } \\
\text { garrien bateratzearen, automatizazio eta kontrolaren, urrutiko era- } \\
\text { giketen eta mantentze lanen I+G (Ikerkuntza eta Garapena). }\end{array}$ \\
\hline INDAR & $\begin{array}{l}\text { Propultsorearen eragintza zuzenaren, hariltze bikoitzeko makina } \\
\text { elektrikoaren, teknologia isilaren, iman iraunkorren teknologien, } \\
\text { hozketa-sistemen optimizazioaren I+G. }\end{array}$ \\
\hline SKV & $\begin{array}{l}\text { Sorgailu elektrikoaren, abiadura aldakor bidezko sorkuntzaren, ins- } \\
\text { trumentazio eta monitorizazio aurreratuaren, efizientzia eta igorpe- } \\
\text { nen optimizazioaren I+G. }\end{array}$ \\
\hline ORMAZABAL & $\begin{array}{l}\text { Ontziaren eta portuaren arteko konexio elektrikoaren, araudiaren } \\
\text { analisiaren, portuko azpiegitura elektrikoaren, behe eta erdi ten- } \\
\text { tsioko konexioaren I+G. }\end{array}$ \\
\hline Lasa Naval & $\begin{array}{l}\text { Ontzi-ingeniaritzaren } \mathrm{I}+\mathrm{G} \text {, egonkortasun azterketak eta analisiak, } \\
\text { araudiaren analisia, egituren analisia }\end{array}$ \\
\hline $\begin{array}{l}\text { Euskal Herriko } \\
\text { Itsas Foroa }\end{array}$ & $\begin{array}{l}\text { Proiektua hedatzeko ekintzak, enpresen ordezkaritza, dibulgazio } \\
\text { ekintzak, ekitaldien antolaketa }\end{array}$ \\
\hline AZTI & $\begin{array}{l}\text { Ontziko ikuskaritza energetikoko sistemen I+G, ORTZE itsasontzi } \\
\text { berriko kudeaketa eta operazio ereduak, goi mailako eskakizunak, } \\
\text { dibulgazio zientifikoa }\end{array}$ \\
\hline PIE-UPV/EHU & $\begin{array}{l}\text { Kudeaketa eta operazio eredua, zientzia dibulgazioa, goi mailako } \\
\text { erabiltzaile-eskakizunak }\end{array}$ \\
\hline $\begin{array}{l}\text { Ingeniaritza } \\
\text { eskola EHU }\end{array}$ & $\begin{array}{l}\text { Barne errekuntzako sorgailu elektrikoen } \mathrm{I}+\mathrm{G} \text {, monitorizazio aurre- } \\
\text { ratua, mantentze lan prebentiboak eta CMS (Content Management } \\
\text { System) teknikak, hedatze eta trebakuntza ekintzak }\end{array}$ \\
\hline $\begin{array}{l}\text { Mondragon } \\
\text { Unibertsitatea }\end{array}$ & $\begin{array}{l}\text { Potentzia eta kontroleko elektronikaren } \mathrm{I}+\mathrm{G} \text {, sareko ikerketak, dis- } \\
\text { tribuzio sistemaren babesa, egonkortasun elektrikoaren analisia, } \\
\text { hedatze eta trebatze ekintzak }\end{array}$ \\
\hline $\begin{array}{l}\text { Blas de Lezo } \\
\text { Pasaiako Itsas } \\
\text { Arrantzako BHI }\end{array}$ & $\begin{array}{l}\text { Goi-mailako eskakizunak, ORTZE itsasontzi berriaren kudeaketa } \\
\text { eta operazio ereduak, operazio profilak, diseinua eta oinarrizko in- } \\
\text { geniaritza, dibulgazioko eta lanbide hezkuntzako ekintzak, ORTZE } \\
\text { itsasontziaren bulegoa/tripulazio nagusia }\end{array}$ \\
\hline Tknika & $\begin{array}{l}\text { Lanbide Heziketari aplikatutako Ikerketa eta Berrikuntzako Euskal } \\
\text { Autonomia Erkidegoko zentroa }\end{array}$ \\
\hline
\end{tabular}




\section{ONDORIOAK}

Industria, ikerketa eta hezkuntza izan dira proiektu honen funtsezko zutabeak (5. irudia). Lehenengoz, INDUSTRIA posizionamendua bultzatuko du, partzuergoko enpresei itsas garraioaren elektrifikazioaren merkatu berrian hazten lagunduko dielako. Parte hartutako enpresa bakoitzak puntako teknologia propioa eta ezagutza erantsi dizkio garapen teknologiko honi. Bigarrenez, itsasontziko azken erabiltzaileak puntan kokatzea ere bilatuko du, IKERKUNTZA ardatza bermatuz. Izan ere, Ortze ontziak itsasoko eta gure kostaldeko ekosistemen ikerketarako ozeanografia ikertzea, gure kostaldeko ekosistemak eta ingurumena ezagutzea eta ingurumenarekiko konpromisoa eta sentsibilizazio urdina garatuko ditu. Gaur egun, itsas ikerketak lan konplexu eta askotarikoak eskatzen ditu, eta oinarrizko ekipamendua ere beharrezkoa da. Besteak beste, 4. taulan, arrantzarako eta itsas ikerketarako kubiertako ekipamendu minimoa adierazten da.

4. taula. Arrantzarako eta ikerketarako oinarrizko ekipamendua.

\begin{tabular}{l|l|l}
\hline \multicolumn{1}{c|}{ Gailua } & \multicolumn{1}{|c}{ Kokapena } & \multicolumn{1}{c}{ Funtzioa } \\
\hline Garabia & $\begin{array}{l}\text { Ontziaren erdialdean, ku- } \\
\text { biertan edo zubi gaineko } \\
\text { kubiertan }\end{array}$ & $\begin{array}{l}\text { Karga lanak, buien aingu- } \\
\text { raketak, itsas ikerketarako } \\
\text { aparatuen erriatzea edo ja- } \\
\text { sotzea (CTD - Conducti- } \\
\text { vity, Temperature Depth- } \\
\text { ROV - Remote Operated } \\
\text { Vehicle-, dragak, etab.) }\end{array}$ \\
\hline $\begin{array}{l}\text { Arrantzarako makina bira- } \\
\text { korrak }\end{array}$ & $\begin{array}{l}\text { Kubiertan zubitik popara } \\
\text { (istriborrean eta ababo- } \\
\text { rrean) }\end{array}$ & $\begin{array}{l}\text { Arrasteroek arrantza opera- } \\
\text { zioan kableak erriatzea eta } \\
\text { jasotzea. Itsas ikerketarako } \\
\text { aparatuen erriatzea edo ja- } \\
\text { sotzea (CTD, ROV, etab.) }\end{array}$ \\
\hline $\begin{array}{l}\text { Garabi edo puntala }+ \text { txi- } \\
\text { rrika }\end{array}$ & $\begin{array}{l}\text { Popan (istriborrean eta } \\
\text { ababorrean) }\end{array}$ & $\begin{array}{l}\text { Arraste operazioan kableak } \\
\text { gidatzeko eta erriatzeko edo } \\
\text { jasotzeko maniobrak ahal- } \\
\text { bidetzea }\end{array}$ \\
\hline $\begin{array}{l}\text { Karretela edo danborra } \\
\text { Bestelako arrantza tresneria } \\
\text { polipastoa) }\end{array}$ & $\begin{array}{l}\text { Arrantza kubierta gainean } \\
\text { (airean) }\end{array}$ & $\begin{array}{l}\text { Subiertan albo batean } \\
\text { lanerako libre utziz }\end{array}$ \\
\hline $\begin{array}{l}\text { Arrain sailkatzeko mahaia } \\
\text { Kesmuntagarria) }\end{array}$ & $\begin{array}{l}\text { Arrantza mota estatikoak } \\
\text { erabiltzea, tertza, linea ber- } \\
\text { tikala, etab. }\end{array}$ \\
\hline Kubiertan & $\begin{array}{l}\text { Arrain sailkatzeko lanak } \\
\text { egitea }\end{array}$ \\
\hline
\end{tabular}


Ekipamendu espezifikoa ikerketa taldeek adierazi behar dute, eta ontziaren hurrengo erronka izango da. Adibidez, ikerketa ontzi ozeanografikoek uraren, atmosferaren eta klimaren ezaugarri fisiko, kimiko eta biologikoei buruzko ikerketak egiten dituzte. Horretarako, sakonera desberdinetako ur-laginak biltzeko ekipoa garraiatu behar dute, eta itsas hondoa aztertzeko sentsore mota ugari eta beharrezko azpiegitura ere izan behar ditu, besteak beste, urpekaritza zientifikoko jarduerak garatzekoa.

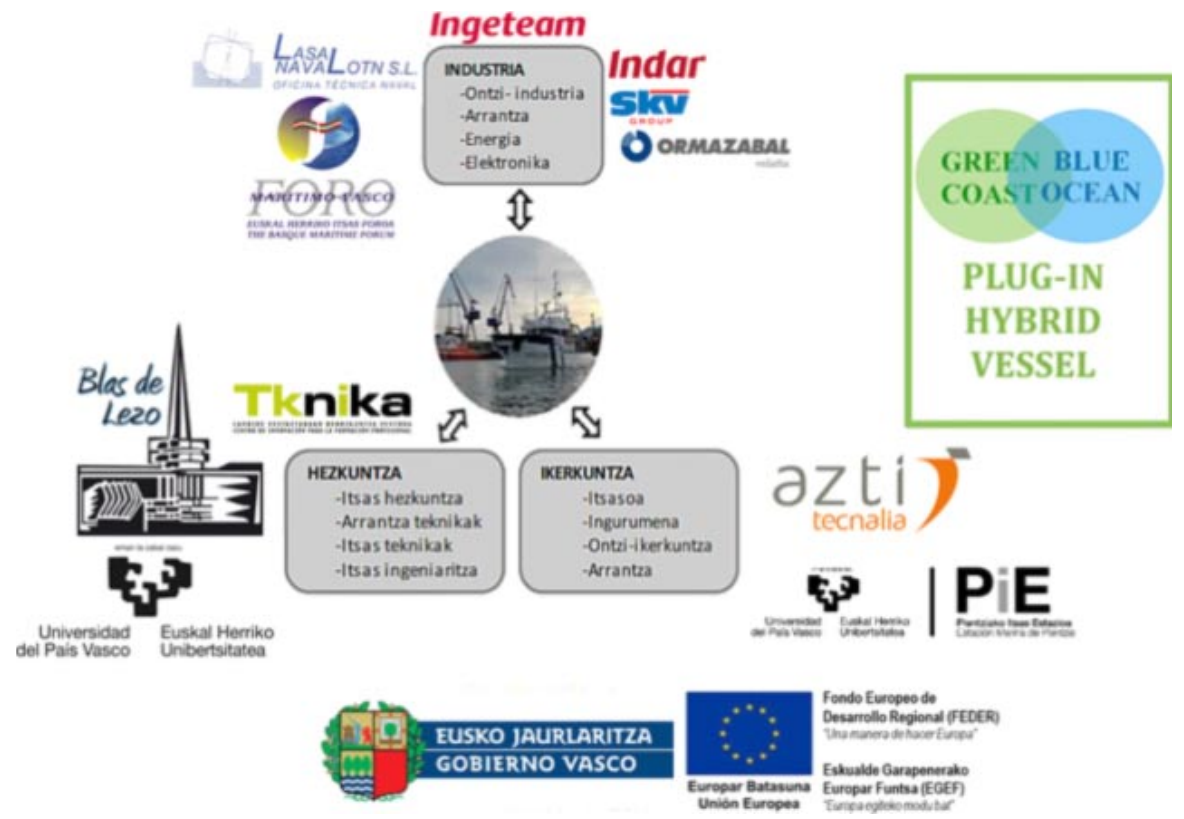

6. irudia. ORTZE-CV proiektuaren ardatz nagusiak.

Hirugarrenez, HEZKUNTZAri dagokionez, Ortze berriztatuak itsaso eta arrantza alorretan etorkizuneko profesionalei, bai eta itsas ingeniariei ere, praktikak eta prestakuntza egitea eskainiko die. Pasaiako Blas de Lezo Itsas Arrantzako BHIko ikasleek teknologia elektriko eta energetiko berrietan oinarritutako praktikak burutzeko aukera izango dute, eta teknologia horiek posible egiten dituzten operazio modu berrietan trebatuko dira. Ortze ontziak masterrak eta doktoregoko ikastaroak bertan irakastea ahalbidetuko du. Adibidez, itsas ingurumenarekin edo ingurumenaren osasunarekin eta biodibertsitatearekin zerikusia daukaten EHUko hainbat masterretako ariketa praktikoak han egin daitezke. Ez graduondoko ikasleek soilik, baita graduetako ikasleek ere (fisikariak, ingeniariak, biologoak, kimikariak, Nautikako ikasleak, etab.) han emenda dezakete itsasoaren eta propultsio makina berritzaile honen inguruko ezaguera. 
Noizko eskuragarri? 2020ko erdialdetik aurrera, Ortze ontziak gure kostaldeko ingurumena eta ozeanografia ikertzeko operazioak hasiko ditu, bai eta trebakuntza, dibulgazio eta kontzientziazio jarduerak ere. Propultsio sistema eta planta elektriko berriak gure kostaldetik ibilbide garrantzitsuak egitea ahalbidetuko du, osasunerako eta ingurugirorako kaltegarriak diren isurketak murriztuz. Hain zuzen ere, portu sarrera eta irteeretan, kostaldetik hurbil, bai eta inguru babestuetan ere, gas eta soinu emisioak zero izango dira.

Laburbilduz, Ortze ontziak gaur egun itsas munduan eta, oro har, garraioan indartsu sartzen ari diren teknologia garbi berrietan sakontzeko eta trebatzeko aukera eskainiko du. Ortze itsasontzi berriztua Euskadin garatu da, eta gure lurraldean arituko den era honetako lehenengo itsasontzia izango da. Energia berriztagarrien munduan nazioarteko erreferente bilakatu nahi da, goi-mailako ikerkuntzan eta hezkuntzan lor daitezkeen emaitza posibleak ahaztu gabe.

\section{ESKER ONAK}

Lehenik eta behin esker onak eman Eusko Jaurlaritzaren Garapen Ekonomiko eta Azpiegitura Sailari, HAZITEK 2017 programaren bitartez, ZE-2017/0005 espediente zenbakidun ORTZE-CV proiektua finantzatzeagatik. Era berean, FEDER 201-2020 programaren barruan Europar Batasuneko kofinantzaketa posiblea egin duen Euskal Programa Eragileari gure esker onak.

Eta azkenik, eskerrik asko proiektu honetako partzuergoa osatzen duten enpresa eta entitate orori, bereziki Pasaiako Blas de Lezo Itsas Arrantzako BHI Institutuari.

\section{BIBLIOGRAFIA}

[1] CORFIELD R. 2003. The Silent Landscape: The Scientific Voyage of HMS Challenger. Int Edition. Joseph Henry Press. 300 or. ISBN-10: 0309095093.

[2] RIGBY N, VAN DER MERWE, P, WILLIAMS, G. 2018. Pacific Exploration: Voyages of Discovery from Captain Cook's Endeavour to the Beagle. Adlar Coles. Edk. 256 or.

[3] https://upload.wikimedia.org/wikipedia/commons/3/32/HMS_Endeavour_ off_the_coast_of_New_Holland\%2C_by_Samuel_Atkins_c.1794.jpg. Endeavour. Webgunea, eguneratze-data: 2019-12-02.

[4] https://hmsbeagleproject.org/rebuild/. HMS Beagle Project. Webgunea, eguneratze-data: 2019-12-02.

[5] https://en.wikipedia.org/wiki/Endurance_(1912_ship). Endurance (1912 ship). Webgunea, eguneratze-data: 2019-12-02. 
[6] https://commons.wikimedia.org/w/index.php?curid=21322316. Albatross. Webgunea, eguneratze-data: 2019-12-02.

[7] https://commons.wikimedia.org/wiki/File:HMS_challenger_William_ Frederick_Mitchell.jpg. HMS Challenger. Webgunea, eguneratze-data: 2019-12-02.

[8] OLAIZOLA SARRIA, JL. 2018. Juan Sebastián Elcano: la mayor travesía de la historia. Biblioteca Online SL Ed. 168 or. ISBN: 8415998953.

[9] SMITH DG.; WILLIAMS JT. 1999. «The Great Albatross Philippine Expedition and Its Fishes». Marine Fisheries Review, 61(4), pp. 31-41.

[10] LANSING A. 2015. Endurance: Shackleton's Incredible Voyage. Basic Books Publ. 3257 or. ISBN. 9780465058785.

[11] VAN DER MERWE, P; MICHELL J. 2018. South: The Race to the Pole. Pieter van der Merwe (Editor), Jeremy Michell (Editor). National Maritime Museum, Greenwich. 208 or. ISBN-10: 1844864863.

[12] MATSEN B. 2010. Jacques Cousteau: The Sea King. Vintage Publ. 320 or. ISBN: 0307275426.

[13] https://en.wikipedia.org/wiki/RV_Calypso. RV Calyspso. Webgunea, eguneratze-data: 2019-12-02.

[14] https://www.eurofleets.eu/vessel/rv-skagerak/. Eurofleets, RV Skagerak. Webgunea, eguneratze-data

[15] KHAN, M. I. (2017). «Falling oil prices: Causes, consequences and policy implications». Journal of Petroleum Science and Engineering, 149, 409-427. doi: http://dx.doi.org/10.1016/j.petrol.2016.10.048.

[16] LETTIERI, S. (2015). El precio del petróleo: La geopolítica en movimiento. Centro de Capitanes de Ultramar y Oficiales de la Marina Mercante. www. capitanes.org.

[17] https://www.oil-price.net/. Oil Price. Webgunea, eguneratze-data: 201912-09.

[18] ROJON, I., eta SMITH, T. (2014). On the attitudes and opportunities of fuel consumption monitoring and measurement within the shipping industry and the identification and validation of energy efficiency and performance interventions. UCL Energy Institute: University College London.

[19] BASURKO, O. C., GABIÑA, G., eta URIONDO, Z. (2013). «Energy performance of fishing vessels and potential savings». Journal of Cleaner Production, 54, 30-40. doi: 10.1016/j.jclepro.2013.05.024

[20] REITZ, R. D. (2013). «Directions in internal combustion engine research». Combustion and Flame, 160(1), 1-8. doi: http://dx.doi.org/10.1016/j. combustflame.2012.11.002

[21] IMO. (2014). Third IMO Greenhouse Gas Study: International Maritime Organization.

[22] FAGERHOLT, K., GAUSEL, N. T., RAKKE, J. G., eta PSARAFTIS, H. N. (2015). «Maritime routing and speed optimization with emission control areas». Transportation Research Part C: Emerging Technologies, 52, 57-73. doi: http://dx.doi.org/10.1016/j.trc.2014.12.010 
[23] CUMMINS (2009). Meeting the Next Challenge: IMO Tier II and III.

[24] ANG, B. W., MU, A. R., eta ZHOU, P. (2010). «Accounting frameworks for tracking energy efficiency trends». Energy Economics, 32(5), 1209-1219. doi: http://dx.doi.org/10.1016/j.eneco.2010.03.011

[25] BOWS-LARKIN, A., SMITH, T., eta WROBEL, P. (2016). «Shipping in changing climates». Marine Policy. doi: http://dx.doi.org/10.1016/j. marpol.2016.05.033

[26] LEE, C.-Y., LEE, H. L., eta ZHANG, J. (2015). «The impact of slow ocean steaming on delivery reliability and fuel consumption». Transportation $R e$ search Part E: Logistics and Transportation Review, 76, 176-190. doi: http://dx.doi.org/10.1016/j.tre.2015.02.004

[27] MANDER, S. (2016). «Slow steaming and a new dawn for wind propulsion: A multi-level analysis of two low carbon shipping transitions». Marine Policy. doi: http://dx.doi.org/10.1016/j.marpol.2016.03.018

[28] BASURKO, O. C., eta URIONDO, Z. (2015). «Condition-Based Maintenance for medium speed diesel engines used in vessels in operation». Applied Thermal Engineering, 80, 404-412. doi: http://dx.doi.org/10.1016/j.applthermaleng. 2015.01.075

[29] SUÁREZ DE LA FUENTE, S., ROBERGE, D., eta GREIG, A. R. (2016). «Safety and $\mathrm{CO}_{2}$ emissions: Implications of using organic fluids in a ship's waste heat recovery system». Marine Policy. doi: http://dx.doi.org/10.1016/j. marpol.2016.02.008

[30] JAIN, S., eta DESHMUKH, S. (2012). «Experimental Investigation of Magnetic Fuel Conditioner (M.F.C) in I.C. engine». Journal of Engineering, 2(7), 27-31.

[31] GABiÑA, G., BASURKO, O. C., NOTTi, E., SAlA, A., ALDEKOA, S., CLEMENTE, M., eta URIONDO, Z. (2016). «Energy efficiency in fishing: Are magnetic devices useful for use in fishing vessels?». Applied Thermal Engineering, 94, 670-678. doi: http://dx.doi.org/10.1016/j.applthermaleng. 2015.10.161

[32] ALPTEKIN, E. (2017). «Emission, injection and combustion characteristics of biodiesel and oxygenated fuel blends in a common rail diesel engine». Energy, 119, 44-52. doi: http://dx.doi.org/10.1016/j.energy .2016.12.069

[33] MEHER, L. C., VIDYA SAGAR, D., eta NAIK, S. N. (2006). «Technical aspects of biodiesel production by transesterification-a review». Renewable and Sustainable Energy Reviews, 10(3), 248-268. doi: http://dx.doi.org/ 10.1016/j.rser.2004.09.002

[34] GABIÑA, G., MARTIN, L., BASURKO, O. C., CLEMENTE, M., ALDEKOA, S., eta URIONDO, Z. (2019). «Performance of marine diesel engine in propulsion mode with a waste oil-based alternative fuel». Fuel, 235, 259268.

[35] BUCKINGHAM, J. (2014). Mapping the Hybrid Solution Space. Shipping in Changing Climates Conference. 
[36] WHITElEGG, I., eta BUCKNALLA, R. (2013). Electrical Propulsion in the Low Carbon Economy. Low Carbon Shipping Conference.

[37] https://www.ortze-cv.com/wp-content/uploads/2018/04/Resumen-ORTZECV-Completo_v10.pdf. ORTZE-CV Proyecto estratégico 2017-2020. Webgunea, eguneratze-data: 2019-12-2. 